DOI https://doi.org/10.30525/978-9934-26-114-5-38

\title{
ФОРМУВАННЯ БІОЕТИКИ У СКЛАДІ ЕКОЛОГІЧНОЇ КОМПЕТЕНТНОСТІ ЗДОБУВАЧІВ ФАХОВОЇ ПЕРЕДВИЩОЇ ОСВІТИ
}

\author{
Рилік М. I. \\ викладач природничих дисциплін \\ Бахмутський фаховий коледж культури і мистеитв \\ імені Івана Карабиия \\ Рилік Н. І. \\ викладач суспільних дисииплін, викладач-методист \\ Бахмутський фаховий коледж культури і мистецттв \\ імені Івана Карабиия \\ м. Бахмут, Украӥна
}

У Національній стратегії розвитку освіти в Україні на 2021-2021 pp. серед перспективних напрямків виділено питання іiі екологізації. Більшість науковців погоджуються 3 таким розумінням екологічної компетентності: категорія екологічної діяльності, пов'язана з екологічною свідомістю, екологічним мисленням та екологічними цінностями.

У праці І. Мунасипової-Мотяш обгрунтовано зростання інтересу до виявлення сутності екологічної компетентності, а саме - рішення глобальної екологічної проблеми, що існує у сучасному світі, неможливе без якісної зміни екологічної культури та екологічної компетентності. Дефініція «екологічна компетентність», на думку дослідниці, набуває універсального, міждисциплінарного, інтегрального і соціокультурного характеру. Конструкт екологічної компетентності $\epsilon$ інтегративним поєднанням здібностей, установок і досвіду творчої діяльності. Їх компонентний зв'язок дозволяє встановлювати екологічні відносини в системі «суспільство - природа - людина». Специфічне поєднання різних здібностей суб'єкта діяльності утворює основу професійної поведінки, спрямованої на вирішення екологічних проблем. Таким чином, екологічна компетентність $є$ основоположним елементом успіху екологічної діяльності. Екологічна компетентність пов'язана з самоорганізацією активних, творчих суб'єктів, здатних на несподівані рішення у складних екологічних умовах [3, с. 149].

Дослідники Н. Вовк та А. Шаповалова, розглядаючи шляхи формування такої ключової компетентності, як «Екологічна грамотність i здорове життя», підкреслюють важливість наявності у 
нормативних документах орієнтації на формування у молоді екологічної культури, заохочення її до активної екологічної діяльності, виховання дбайливого ставлення до природних багатств. Науковці твердять, що сталий розвиток $є$ новим принципом людського спільного життя, відповідно до якого людство повинно узгоджувати свою діяльність із законами природи, змінювати споживче ставлення до неї та бути готовим і здатним не лише визначати екологічні проблеми, а й знаходити раціональні шляхи їх вирішення [1, с. 57-58].

Порушуючи питання формування ціннісних орієнтацій у системі «людина - навколишнє середовище», Яковець О. Р. твердить, що вони були актуальні ще в історії педагогічної думки часів Київської Русі та органічно поглиблювались у роботах М. Корф, К. Ушинського, С. Русової, В. Сухомлинського та ін. У сучасній науковій літературі (О. Вишневський, Т. Єфіменко, М. Колесник, Є. Копилець, Л. Морозова, А. Шевель та ін.) дефініцію «екологічні цінності» вченими витлумачено як особистісно зумовлену значущість об'єктів довкілля в межах соціального буття, що визначається прийняттям екологічних очікувань і установок, знань, емоцій, поведінки, оцінок, переконань, намірів, дій відносно сучасних і майбутніх подій екологічного змісту [5, с. 108].

Нам видається життєво важливим посилення аксіологічної складової особистості майбутнього фахового молодшого бакалавра формуванням таких екологічних ціннісних орієнтацій, як: екологічна грамотність, екологічна культура, орієнтація на екологічну діяльність, біоетика. Особливу увагу ми пропонуємо приділити у викладацькій діяльності біоетиці як ціннісній орієнтації.

У роботі П. Магди біоетику витлумачено як комплексну ціннісну орієнтацію, призначену для осмислення і пошуку шляхів вирішення проблем у системі «життя - діяльність - цінність», для сприяння реалізації морального імперативу виживання людства. У іiі складі дослідниця пропонує виділити такі елементи, що становлять основу, але не вичерпують усю структуру ціннісної орієнтації (подано у контексті естетико-екологічної культури):

- пошук і оновлення екологічно виправданих аксіологічних підходів до природи, що зумовлює загальну гуманістичну орієнтацію особистості;

- пошук власної екологічно доцільної виховної стратегії, що вимагає виконання еколого-виховних завдань;

- освоєння доробку митців, у якому відбито досвід культурних форм освоєння природи;

- наявність концепції виховання ціннісного ставлення до природи;

- професіоналізація естетичних та екологічних знань тощо $[2$, c. 381$]$. 
О. Шукатка у своєму дослідженні наголошує на необхідності оновлення змісту природничої, методичної, психологічної підготовки викладачів природничих дисциплін, використанні різноманітних педагогічних технологій, форм, методів і засобів навчання, підвищенні пізнавальної активності здобувачів освіти, їх самостійності в набутті природничо-наукових знань тощо. Науковець відмічає, що науки природничого циклу дедалі більше набувають людського виміру, наближаються за стратегією дослідження до гуманітарних наук, а серед складників їх методологічного й соціокультурного арсеналу з'являються категорії: добро, благо, обов'язок, етика тощо [4, c. 499].

Ми повністю погоджуємося з думкою дослідника і пропонуємо такі шляхи удосконалення викладання природничих дисциплін у коледжах фахової передвищої освіти для формування біоетики у межах екологічної компетентності здобувача:

- розробка інтегрованих навчальних програм 3 культурології, природничих наук (біологія, екологія), природничих наук (фізика, астрономія, географія), основ філософських знань, соціології (назви дисциплін наведено згідно 3 навчальним планом спеціальності 025 Музичне мистецтво 2018 року);

- формування у процесі викладання названих дисциплін мотивації до удосконалення аксіологічної складової спрямованості особистості здобувача (педагогіка емпауерменту);

- акцент на створенні середовища взаємодії (здобувач - викладач) для реалізації завдань екологічної діяльності;

- створення силами викладачів циклової комісії школи екологічного зростання особистості (позаурочна виховна робота, самостійна робота здобувачів, спрямована на підвищення екологічної грамотності, формування екологічної культури, екологічну діяльність, прагнення до здорового способу життя тощо);

- максимальне використання аксіологічної потужності названих дисциплін за заняттях та у дослідницькій роботі здобувачів освіти;

- застосування нестандартних форм і методів освітньої діяльності (технологія екологічного проектування як засіб формування емоційноціннісного ставлення до природи, екологоспрямована діяльність товариства молодих науковців закладу освіти, екочелендж, екофлешмоб для залучення широкого кола молоді до розв'язання екологічних проблем сьогодення тощо).

Названі шляхи удосконалення викладання природничих дисциплін у коледжах фахової передвищої освіти для формування біоетики у межах екологічної компетентності здобувача, звичайно, не претен- 
дують на універсальність і вичерпність, проте є однією з альтернатив оптимізації шляхів розв'язання окресленої проблеми.

\section{Література:}

1. Вовк Н. В., Шаповалова А. П. Формування екологічної компетентності учнів у процесі реалізації змістової лінії «Екологічна безпека та сталий розвиток» на уроках трудового навчання. Матеріали Міжнародної науково-практичної Інтернет конференції, присвяченої 80-річчю заснування ДВНЗ «ДДПУ» та 50-річчю започаткуванню підготовки вчителів трудового навчання в ДДПУ «Проблеми професійного розвитку вчителя в контексті оновлених освітніх стандартів». Слов'янськ: ДДПУ. 2020. С. 57-60.

2. Магда П. М. Біоетика майбутнього вчителя музики: підходи до тлумачення. Педагогіка формування творчої особистості у вищій $i$ загальноосвітній школах: зб. наук. пр. Запоріжжя: КПУ. 2018. Вип. 58-59. С. 380-386.

3. Мунасипова-Мотяш І. А. Особливості екологічної компетентності та екологічних установок студентів різних спеціальностей. Актуальні проблеми психології. Т. 7. Вип. 42. С. 148-155.

4. Шукатка О.В. Проблема вивчення дисциплін природничого циклу крізь призму реалізації завдань професійної підготовки майбутніх бакалаврів природничих спеціальностей. Педагогіка формування творчої особистості у вищій $i$ загальноосвітній школах: зб. наук. пр. Запоріжжя: КПУ. 2018. Вип. 58-59. С. 496-503.

5. Яковець О.Р. Формування екологічних цінностей майбутніх вчителів початкової школи у процесі професійної підготовки. Психологія та педагогіка: необхідність впливу науки на розвиток практики в Україні. Львів: ГО «Львівська педагогічна спільнота». 2018. Ч. 2. С. $107-110$. 